\title{
Tax Burden Implication of Tax Reform
}

\author{
Yinka Mashood Salaudeen*, Tayibat A. Atoyebi \\ Department of Accounting, University of Abuja, Abuja, Nigeria \\ Email: *yinka.salaudeen@uniabuja.edu.ng, tayibat.atoyebi@uniabuja.edu.ng
}

How to cite this paper: Salaudeen, Y.M. and Atoyebi, T.A. (2018) Tax Burden Implication of Tax Reform. Open Journal of Business and Management, 6, 761-777. https://doi.org/10.4236/ojbm.2018.63058

Received: June 25, 2018

Accepted: July 27, 2018

Published: July 30, 2018

Copyright (c) 2018 by authors and Scientific Research Publishing Inc. This work is licensed under the Creative Commons Attribution International License (CC BY 4.0).

http://creativecommons.org/licenses/by/4.0/

Open Access

\begin{abstract}
This study examines the effect of the 2007 reform pertaining to the corporate tax system on the tax burden of listed firms in Nigeria using the t-test and canonical correlation analysis. Data were collected from the financial statements of the 86 sampled firms for the period 2003-2011 subdivided into pre-reform (2003-2006) and post reform (2008-2011) sub-periods for the purpose of comparing periods' tax burdens. Data were also segregated along the Nigerian Stock Exchange industrial sector classifications. This study finds, on the whole, that the 2007 corporate tax reform has brought minimal tax burden on listed firms, however, sectoral analysis reveals the heterogeneity in the effect of the tax reform as firms within the agricultural and natural resources sectors witnessed increases in tax burden while firms in health and oil and gas sectors were favoured with reduced tax burden. The tax burden of other sectors is unaffected by the reform.
\end{abstract}

\section{Keywords}

Canonical Correlation, Tax Reform, Tax Burden, Pre-Reform, Post-Reform

\section{Introduction}

Changes do occur in the economic, political and social characteristics of nations, some as dictated by the actions and policies of government. In keeping with the dynamic nature of nations, tax laws are continuously reviewed and amended (tax reform). When amendments are made to tax laws which change the procedures for the determination of the tax liability (tax burden), there exits the possibility that the tax burden of persons chargeable with tax may not remain constant even if the chargeable income remains constant from hitherto. The law governing the corporate tax system in Nigeria, the Companies Income Tax Act (CITA), originally promulgated in 1961, has witnessed several reforms including the repeal and re-enactment of 1979 and 1990 (Sanni, 2011) [1]. The latest reform is contained in Companies Income Tax (Amendment) Act, 2007. The 2007 
reform, inter alia, makes wide provisions for the taxation of companies engaged in insurance activities, reviews the procedure for the granting of tax exemption to firms situated in Export Processing Zones, allows donations of capital nature to universities and research institutions, extends the period of carry forward of loss to infinity and abolishes the investment tax credit grantable to firms engaged in the fabrication of local plants and those using them for the purposes of their businesses. Against the backdrop of these changes to the principal act, concerns arise as to the equity of the corporate tax system in Nigeria. This study addresses this issue by examining the effect of these changes (tax reform) on the tax burden of listed firms and the magnitude and direction of any such effect.

Several studies have examined the issue of how tax reforms affect tax burden, these include the studies of Spengel, C., Ortmann-Babel, M., Zinn, B. and Matenaer, S. (2012) [2] who simulate the effect of the adoption of the proposed common tax base in the EU on tax burdens of member states, Roggeman, A., Verleyn, I., Van Cauwenberge, P., and Coppen, C. (2014) [3] who did same in Belgium and Spengel, C., Lazar, S., Evers, L., and Zinns, B. (2012) [4] who examine the effects of the various tax reforms on tax burden in Romania. Fang, H., Bao, Y. and Zhang, J. (2017) [5] investigate the tax burden effect of VAT Pilot Programme in China and Oropallo, F. and Parisi, V. (n.d) [6] investigate the effect of the 2004 business tax reform in Italy on corporate tax burden. In the $\mathrm{Ni}$ gerian contest, the handful empirical studies on tax reforms concentrate on the economic development impact of the reforms (Jelilov, Abdulrahman and Isik, 2017 [7]; ...; Ogbonna and Ebimobwei, 2012 [8]) and the revenue productivity impact (Oti and Odey, 2016 [9]; Asaolu, Dopemu and Monday, 2015 [10]; Oriakhi and Ahuru, 2014 [11]). This leaves the impact of tax reforms on tax burden unexamined and unattended to in Nigeria. Therefore, this study investigates the effect of the 2007 corporate tax system reform on corporate tax burden.

This study advances existing literature in several ways, one, by obtaining company level data relating to tax burden for the periods before and the periods after the tax reform to discover any changes in tax burden, thereby providing empirical evidence of the impact of tax reform as against the more common reliance on theoretical simulations and predictions approach (Auberach, 1996) [12]. Second, it has contributed to scarce literature on the effects of tax reform in Nigeria. Moreover, investigating the effect of tax reform reveals the performance of that reform, gives feed back to the policy makers and guides future tax reform policies. The findings of this study, therefore, guide tax policy makers. Additionally, an average of $22 \%$ of the federally collectible revenue in Nigeria from 2012-2015 accrues from firms chargeable under the CITA (FIRS, 2012, [13]), what happens to the tax burden of this single large group of tax payers should be of concern to any government in order to ensure an uninterrupted flow of revenue to maintain and finance development. Hines Jr., J.R. (2017) [14] also observes that taxes on business activities that discourage the formation and expansion of businesses, indeed, Spengel et al. (2012) [2]; Hebows, S., Ruf, M., and Weichenvieder, A.J. (2011) [15] find tax to determine how attractive a country is 
as a destination for investments. Evidences also abound of firms relocating from one country to another as a consequence of the level of tax burden.

The results of this study reveal, on the whole, that the 2007 reform has brought no additional tax burden on listed firms; however, the sectoral analysis suggests that the effect of the reform is not homogeneous across the industrial sectors. While the agricultural and natural resources sectors witnessed increases in their tax burden, the health and oil and gas sectors benefited from the reform by a reduction in their tax burden, the effect is neutral in other sectors.

Further discussion in the paper proceeds as follows: the next section, section two presents a review of tax reforms, and the methodology adopted in the study, section three presents the results of the study; section four presents concluding remarks.

\section{Tax Reforms}

\subsection{Corporate Tax Reforms in Nigeria}

The corporate tax system in Nigeria is governed by the Companies Income Tax Act (CITA) originally promulgated in 1961. This principal act has witnessed several amendments (reforms). Odusola, A. (2006) [16] classifies the various reforms into pre-1992 and post-1992 reforms, opining that the pre-1992 reforms were narrow based, overburden the tax payers and negatively affect savings and investments. The post-1992 reforms were considered to be more tax payer friendly and offer more incentives for businesses to thrive. Before 2007 and after 1992 reforms were made to the principal act in 1993, 1996, 1998, and 1999 (FIRS, 2012) [13].

The process leading to the 2007 reform includes the setting up of a Study Group and subsequently the Work Group. The Study Group, inter alia, had the mandate to review all aspects of the Nigeria Tax System including its tax laws, consider international developments for adoption in Nigeria and evaluate the need for the retention of all tax incentives available in the country (Sanni, 2011) [1]. The Work Group was set up to rework the recommendations of the Study Group. The recommendations of the Work Group form the fulcrum of the general tax reforms (including the corporate tax reform of 2007) which were undertaken to secure a better tax system and improvement in tax administration in the country.

Table 1 summaries the changes to the corporate tax system between 1993 and 2007.

\subsection{Review of Related Studies}

Studies have attempted to find relationship between these reforms and some aspects of the Nigerian national life especially their economic growth and revenue productivity impacts. For example, Nworgu, I.A., Herbert, W.E., and Onyilo, F. (2016) [18] examine the impact of tax reforms on national income using OLS analytical tool. Tax reforms were proxied by various tax types in Nigeria 
Table 1. Corporate tax reform 1992-1999.

Reduces the corporate tax rate from $40 \%$ to $35 \%$

- Research and development becomes tax deductible

1993

- Modifies the conditions for the granting of investment allowance

- Introduces Investment Tax Credit (ITC) on facilities provided by companies situated in the rural areas in the absence of government facilities

- Establishes a Technical Committee in the Federal inland Revenue Services (FIRS)

Reduces corporate tax rate from $35 \%$ to $30 \%$

- Expands the qualifying capital expenditure types for capital allowance

- Significantly improves the rates of initial and annual allowances in capital allowance

- Introduces $15 \%$ ITC on replacement plant expenditure and accelerated capital allowance of $95 \%$ on the new plant

- $20 \%$ ITC to companies engaged in research and development activities

- $100 \%$ capital on plant and building expenditure incurred by firms in the Export Processing Zones

- Exempts from tax the profits of firms engaged in . manufacturing activities for export for the first three years of being in operation . supply of materials to firms engaged in manufacturing activities for export . mining of solid minerals for the first three years of being in operation . exported goods where the proceeds are repatriated in the form of raw materials, plants and equipment of spare parts $.25 \%$ of income of hotels received in convertible currencies

- Exempt from tax dividend distributed by

Unit Trust

. small firms engaged in manufacturing activities for the first five years of operation . wholly export oriented businesses

- Introduces self assessment returns filling and payment of advance company tax

Grants incentives to firms engaged in the utilisation of gas for a period not less than 3years but not more than 5 years

- Grants accelerated annual allowance of $90 \%$ and $15 \%$ investment allowance at the expiration of the incentive period $\ldots$

Increases the investment allowance for gas utilisation to $35 \%$

Provides extensive guidelines for the taxation of firms engaged in insurance businesses

- Abrogates: rural investment allowance on provision of telephone services for the purpose of business in the rural areas ITC on replacement on business plants ITC enjoyed by firms fabricating local plants

ITC enjoyed by firms employing locally fabricated plants for business purposes $1 \%$ of tax payable tax incentive for filling self assessment returns

2007 - Extends

. exemption of tax on interest income on bank loan granted to cottage industry participants against the initial restriction to those established under the Family Economic Advancement Programme

. the period of carry forward of business losses from four years to infinity

- Allows donations of capital nature made to universities and research institutions

- Increased the proportion of total profit allowable as donation to $15 \%$ from $10 \%$

- Makes the filling of self assessment return compulsory, hitherto it had be voluntary

Source: Compiled from Compendium of Tax and Related Laws (FIRS, 2012) [17].

and national income by Gross Domestic Product (GDP). On the whole the study finds tax reform to significantly impact nation income, however, the insignificant relationship between Petroleum Profit Tax (PPT), Companies Income Tax (CIT) and Custom Duties (CD) and significant relationship between Personal Income Tax and Value Added Tax question the reliability of the findings since about $80 \%$ of the revenue of the federal government is derivable from combined sources of PPT, CIT and CD. Further, these results contradict the earlier similar work of Ogbonna, G.N. and Ebimobowei, A. (2012) [8] which adopts similar proxies and uses the same technique. The study of Ogbonna, G.N. and 
Ebimobowei, A. finds PPT, CIT, and CD to be significantly related economic growth in a positive manner. Jelilov, G., Abdulrahman, S. and Isik, A. (2016) [7] also examine the effect of tax reforms on economic growth in Nigeria and find tax reform to promote economic development and revenue accruable to government. The use of tax types to represent tax reforms is common to the foregoing studies which may not be considered appropriate. The study of Oriakhi, D.E. and Ahuru, R.R. (2014) [11] obtains various tax type data to represent tax reforms and carries out the Johansen Co-integration Test to examine the impact of tax reform on revenue generated by the Federal Government of Nigeria (FGN). The test reveals a long term positive relationship between two. This result supports the earlier study of Oti, P.A. and Odey, F.I. (2011) [9]. All these studies suffer from their inability to isolate significant milestones in tax reforms during the periods of their studies (several reforms were undertaken during the periods) in order to examine their respective effects in addition to their inappropriate representation of tax reform.

Asaolu, T.O., Dopemu, S.O. and Monday, J.U. (2015) [10] identify the various reforms to the tax administration machineries of the Lagos State Government (LSG) in order to find their effects on the revenue generating capacity of the LSG. Albeit no significant changes in revenue was noticed between 1999 and 2005 (when the reform activities had not picked up), sharp increases in revenue was noted between 2006 and 2014 (when the reforms actually took place).This study, therefore, concludes that tax administration reforms have actually resulted in high increase in revenue accruing the state government.

Olodo, H.F. (2014) [19] deviates for the economic and revenue impacts of tax reform to examine tax administrative efficiency effect of tax reforms from 1978 to 2012 (when the last tax law type, the Personal Income Tax Act, was reviewed). Adopting a doctrinal approach, the study finds tax reforms to have created a more tax payer friendly environment, improved the quality of tax personnel and their welfare and provides greater accessibility. The study also reveals great improvement in procedures with adoption of modern communication technology.

The introduction of VAT Pilot Programme in China in 2012 was predicated on reducing the high tax burden experienced by firms within the service industry and to examine the success or otherwise of the programme, Fang, H., Bao, Y, and Zhang, J. (2017) [5] develop a theoretical model and apply Difference-in-Difference (DID) framework. The study finds the programme to have reduced the tax burden of small scale tax payers but the effect on the general tax payers is not significant.

Following the proposal of a Common Consolidated Corporate tax Base (CCCTB) by the European Commission for the EU, Spengel, C., Ortmann-Babel, M., Zinn, B., and Mantenaer, S. (2012) [2] simulate effect of the proposal on the tax burden of member states. The study finds tax burden to be generally unaffected, albeit, some gainer and looser states were found (but not mentioned). However, in a similar work restricted to Belgium, Roggedman, A., Verleyen, I., Van Cauwenberge, P. and Coppen, C. (2014) [3] find that the adoption of the 
common base will significantly increase the average tax burden by $16 \%$. It is difficult to know whether Belgium is one of the losers states identified by Spengel et al. (2012) [2] but the seeming conflicting results suggests the results of large scale study may not be applicable to the individual components.

Spengel, C., Lazar, S., Evers, L. and Zinn, B. (2012) [4], inter alia, examine the effect of the various tax reforms by the Romania government from 1992 to 2012 on the effective tax burden (ETB) of firms. The study computes the ETB at different miles stones (representing the point of each reform) and locates differences in ETB across the various milestones. The results show gradual reduction in tax burden that finally amounts to about $65 \%$, however, the magnitude and direction of the effects are not homogeneous across all sectors of the economy.

Oropallo, F. and Parrisi, V. (n.d) [6] estimates the effect of the 2004 corporate tax reform in Italy of tax burden of firms by developing a static micro-simulation model of the Italian corporate tax system based on integrated data that combines company level data survey data. The simulation results suggest a minimal increase in tax of about $0.26 \%$ in respect of the pooled data and significant reduction in tax burden of some individual sectors while other sectors' burdens remain unchanged. In the same vein, Anderson, J.F. (2013) [20] examines the effect of the tax reforms in the USA from 1979 to 2003 on the tax burden using the average tax rate as on measure of tax burden of individual person tax payers; findings of this study suggest a consistent reduction in tax burden for all income groupings with pockets of increase in tax burden especially following the 1993 reform where increases were noted in the Top1 Top 10 and Top 20 groupings.

Apart from the measure of tax burden effect of tax reforms, the effect of tax reforms on other aspects of national lives have been examined in literature, for example Abdel-Mowla, S.A.A (2013) [21] investigates how tax reforms in Egypt have addressed the issue of tax obstacles and tax evasion in that country. Tax obstacles are identified as high tax rates and tax administration bottlenecks. A descriptive analytical comparative approach was adopted. Results show that since 2005, reductions have been recorded in the incidence and severity of tax bottlenecks, but in spite of this, evidence still persist of tax obstacles in the area of investment promotion and the rate of tax evasion is still considered high. Further, Choi, Y., Hirata, H., and Kim, S. (2017) [22] examine the welfare effect, inter alia, of cuts in corporate tax rate (representing a reform) in Japan. Dividing the economy into tradable and non tradable sectors and constructing a baseline model that uses dynamic scoring to predict the consequence of the tax reform, the outcome of the simulations reveals that a 5\% reduction in tax rate will increase welfare by $0.53 \%$ when there is no restriction to international borrowing. and that cut in corporate tax rate will encourage better welfare for tradable sector than the no tradable sector. Similarly, Bhattarai, K.R (2007) [23] examines the welfare effect of equal yield tax reform in the UK economy. Specifying a multi-sectoral dynamic general equilibrium tax model which permits numerical expressions of the decentralised market over a period of sixty five years, the 
study compares the impact of anticipated and unanticipated tax reforms on welfare (measured in terms of investment, capital accumulation, output and employment). The study finds that the welfare effect of equal yield tax reform can increase by $1.4 \%$ of the base year GDP when tax distortion is removed and about $2.05 \%$ welfare decrease can occur with distortionary taxes. It also finds that tax payers can adjust their behaviours economically with anticipated tax reforms, that is, when changes to tax rules are announced in advance.

Hallerberg, M, and Scartasani, C. (2016) [24] attempt to answer the question of whether election and banking sector crises engineer tax reforms and tax burden in Latin America. Their study adopts an empirical model subject to OLS analysis. The result shows that impending election and banking sector crises are prominent factors in deciding whether or not there will be tax reforms and consequently increase or decrease in tax burden and the direction and distributions are explained by these factors. Peter, V.M, Kerr, I.A. and Thorpe, M. (2002) [25] examine the effect of various tax reforms that took place in India between 1950/51 and 1994/95 tax years, which result into lowering the tax rates, on private capital formation. The ratio of capital formation is found to reduce by about $0.12 \%$ with an increase in the ratio of direct tax. Also, Kryvoruchko, I. (2015) [26] examines the employment effect of replacing progressive tax rates with a flat tax rate in the 2001 tax reform in Russia. Kryvoruchko classifies employment into primary and secondary and official and unofficial. Findings suggest that, albeit, the total number of labour hours supply reduced with the introduction of the flat rate, the labours hour supply was not affected by the reform in the official and unofficial labour markets.

Okamoto, A. (2007) [27] and Feltenstein, A., Majia, C. Newhouse, D. and Sedrakyan, G. (2017) [28] stimulate the possible effect of tax reforms. While Okamoto estimates the potential welfare effect of introducing progressive expenditure taxation in Japan, Feltenstein et al. simulate the effect of changes in sales and corporate tax rates on consumption and poverty in Pakistan. The simulation result of Okamoto study reveals that the progressive expenditure taxation possesses greater advantage over the subsisting law income tax in terms of efficiency and equity. It also has the propensity to lead to welfare gain. The Feltenstein et al. work which employs simulation in the context of dynamic computational general equilibrium (CGE) and also links the CGE model to household data in a micro simulation model finds that equal yield increase in sales and corporate taxes have differing effect on consumption and poverty.

\subsection{Description of Method}

\subsubsection{Sample and Data}

This study uses firms listed on the Nigerian Stock Exchange (NSE) as units in the inquiry and only 86 out of the 260 firms listed thereon during the period of the study (2003-2011) satisfy the conditions for admission into the sample of this study. To qualify for selection as a member of the sample, a firm must have been listed by 2003 and still maintains listing by the end of 2011. It must also have 
available complete financial statements for the entire period of the study. The sample size selection process is presented in Table 2.

Of the 260 firms listed during the period, 58 were not listed at as at the beginning of the study period (2003) and 73 were no longer listed at the end of the study period (2011) leaving 129 firms that were listed in 2003 and still maintained listing as at 2011. Out this, financial statements could not be obtained for the entire period of study in respect of 43 firms, the remaining 86 firms form the sample of this study. The procedure for the determination of the sample size is summarized in Table 2.

Data were extracted from the financial statements of the sampled firms for the period of the study 2003 to 2011 . The period of study was delineated along two scenarios; 2003-2006 representing the pre-reform period and 2008-2011 representing the post reform period. 2007, being the year of change, was omitted in line with the observation of Guenther, D.J. (1994) [29] and Dhaliwal, D. and Wang, S. (1992) [30] that the effect of tax reform will begin to be felt only after one year. One of the major amendments to the principal act in 2007 is the extensive provisions for the taxation of insurance firms, this represent a sectoral inclination, because of this and in view of the assertion that corporate tax has different effects on different industrial settings (Davis and Henrekon, 2005), this study further divides data along the NSE industrial sector classifications to examine the independent sample tax burden effect of the reform.

\subsubsection{Analytical Framework}

The sole variable of this study is Tax Burden. Following Hine Jr, J.R. (2017) [14]; Anderson, J.F (2013) [20] and several other authors, tax burden is estimated using the Effective Tax Rate (ETR). The concept of ETR developed out of the need to ascertain the actual tax burden borne by tax payers in view of the failure of the Statutory Tax Rate (STR) to effective capture the whole essence of a tax system (NIcodeme, 2001) [31]. This concept has been generally accepted as a good measure of tax burden (Scholes and Wolfson, 1992) [32]. ETR can be defined as tax expenses divided by profit. However both the numerator and the denominator are capable of many connotations. This study adopts the definition of tax expenses contained in IAS 12 (International Accounting Standards Board, 2012) [33] as current tax expenses plus deferred tax provision and profit as profit before tax as argued in Salaudeen, Y.M. and Akano, R.O. (2018) [34]. Thus, effective tax rate is here defined as the ratio of current income tax plus deferred tax provision to the profit before tax.

Data on tax burden were subjected to two types of analysis, the t-test and Canonical Correlation Analysis. The t-test is used to find differences between tax burdens, pre-reform and post-reform. The presence of any significant difference signifies that the 2007 reform affects the tax burden of firms. The Canonical Correlation Analysis (CCA) is used to determine the magnitude of the effect.

CCA is a multivariate statistical method which determines the linear relationship between two sets of multivariate variables a $X$ variable set $\left(x_{1}, x_{2}, \cdots, x_{n}\right)$ 
Table 2. Sample reconciliation.

\begin{tabular}{lcc}
\hline $\begin{array}{c}\text { Total Number of Firms listed } \\
\text { during the period of study }\end{array}$ & 260 \\
\hline $\begin{array}{l}\text { Less: Firms not listed by } 2003 \\
\text { Less: Firms not listed by } 2003\end{array}$ & 58 & 131 \\
Less: Firms with missing financial & 73 & 129 \\
statements & 43 \\
Sample size & 86 \\
\hline
\end{tabular}

and a $Y$ variable set $\left(y_{1}, y_{2}, \cdots, y_{n}\right)$ related by common measurement. Given two column vector $Z_{1}=\left(x_{1}, \cdots, x_{n}\right)$ and $Z_{2}=\left(y_{1}, \cdots, y_{n}\right)$ of random variables with finite second moments, one may define the cross covariance $\Sigma x y=\operatorname{cov}(x y)$ to be the $n x$ in matrix whose $(i, j)$ entry is the covariance $\operatorname{cov}\left(x_{p}, y_{i}\right)$.

Let's consider two variables, $Z_{x}$ and $Z_{y}$, the first a linear combination of $p$ and the second a linear combination of $q$ variables. That is

$$
Z_{1 x}=u_{1} X_{1}+\cdots+u_{p} X_{p}
$$

and

$$
Z_{2 y}=v_{1} Y_{1}+\cdots+v_{q} Y_{q}
$$

where;

$X \mathrm{~s}=$ the $p$ variables in one set;

$Y \mathrm{~s}=$ the $q$ variables in the other set;

and $u$ 's and $v$ 's are weights in the linear combination.

Considering $Z_{x}$, we can show that the mean is

$$
Z_{1 x}=u_{1} X_{1}+\cdots+u_{p} X_{p}
$$

We now define

$$
\begin{gathered}
z_{1 x}=Z_{1 x}-\bar{Z}_{1 x}=u_{1} X_{1}+\cdots+u_{p} X_{p}-u_{1} \bar{X}_{1}-\cdots-u_{p} \bar{X}_{p} \\
=u_{1}\left(X_{1}-\bar{X}_{1}\right)+\cdots+u_{p}\left(X_{p}-\bar{X}_{p}\right)
\end{gathered}
$$

Squaring and summing over $\mathrm{n}$ observation gives

$$
\begin{aligned}
\sum z_{1 x}^{2}= & u_{1}^{2} \sum\left(X_{1}-\bar{X}_{1}\right)^{2}+\cdots+u_{p}^{2} \sum\left(X_{p}-\bar{X}_{p}\right)^{2}+2 u_{1} u_{2} \sum\left(X_{1}-\bar{X}_{1}\right)\left(X_{2}-\bar{X}_{2}\right) \\
& +\cdots+2 u_{p-1} u_{p} \sum\left(X_{p-1}-\bar{X}_{p-1}\right)\left(X_{p}-\bar{X}_{p}\right) \\
= & u_{1}^{2} S_{11}+\cdots+u_{p}^{2} S_{p p}+2 u_{1} u_{2} S_{12}+\cdots+2 u_{p-1} u_{p} S_{p-1 p}
\end{aligned}
$$

in which $S_{j k}=\sum_{i=1}^{2}\left(X_{i j}-\bar{X}_{j}\right)\left(X_{i k}-\bar{X}_{k}\right) ; j, k=1, \cdots, p$.

in matrix form

$$
u=\left[\begin{array}{c}
u_{1} \\
\vdots \\
u_{p}
\end{array}\right]
$$

and 


$$
S_{x x}=\left[\begin{array}{cccc}
S_{11} & S_{12} & \cdots & S_{1 p} \\
\vdots & \vdots & \ddots & \vdots \\
S_{p 1} & S_{p 2} & \cdots & S_{p p}
\end{array}\right]
$$

Then the expression for $\sum z_{x}^{2}$ may be written

$$
\sum z_{x}^{2}=u^{\prime} S_{x x} u
$$

and similarly,

$$
\sum z_{y}^{2}=v^{\prime} S_{y y} v
$$

And

$$
\sum z_{x} z_{y}=u^{\prime} S_{x y} v
$$

where;

$$
\begin{gathered}
v=\left[\begin{array}{c}
v_{1} \\
\vdots \\
v_{q}
\end{array}\right], \\
S_{y y}=\left[\begin{array}{cccc}
S_{11} & S_{12} & \cdots & S_{1 q} \\
\vdots & \vdots & \ddots & \vdots \\
S_{q 1} & S_{q 2} & \cdots & S_{q q}
\end{array}\right]
\end{gathered}
$$

and

$$
S_{x y}=\left[\begin{array}{cccc}
S_{x_{1} y_{1}} & S_{x_{1} y_{2}} & \cdots & S_{x_{1} y_{q}} \\
\vdots & \vdots & \ddots & \vdots \\
S_{x_{p} y_{1}} & S_{x_{p} y_{2}} & \cdots & S_{x_{p} y_{q}}
\end{array}\right]
$$

Using equation (0.09), (0.10) and (0.11), the correlation coefficient $r_{z_{1} z_{2}}$ is

$$
r_{z_{x} z_{y}}=\frac{\sum z_{1 x} z_{2 y}}{\sqrt{\sum z_{1 x}^{2} \sum z_{2 y}^{2}}}=\frac{u^{\prime} S_{x y} v}{\sqrt{\left(u^{\prime} S_{x x} u\right)\left(v^{\prime} S_{y y} v\right)}}
$$

\section{Results}

\subsection{Descriptive Statistics}

Table 3 shows the summary of the summary (descriptive) statistics of the tax burdens during the pre-reform and post-reform study periods. The table reveals the existence of no wide variation in tax burden between the periods as depicted by the descriptive statistics values. The mean tax burden before the promulgation of the reform act stands at $16.2 \%$ which is fairly comparable with the post reform tax burden mean of $21.19 \%$. The standard deviations and variances of both periods' tax burden are also similar at $21.77 \% / 21.05 \%$ and $4.7 \% / 4.4 \%$ respectively.

Figure 1 highlights the average tax burden over the last four years before the tax reform act was promulgated plotted upon the tax burden of the first four years after the tax reform. It can be observed from the table that both the pre and 
post reform tax burden took off almost at the same rate (2003\2008) at $18.52 \%$ and $19.57 \%$ respectively. The difference in tax burden between corresponding years is widest in 2004/2009, with the figure for 2009 at $31.98 \%$ while that of 2004 stands at $16.91 \%$. The tax burden of both periods was the same around 2005\2010. Generally, the post-reform tax burden volume is seen to be higher that the pre-reform tax burden.

The average sectoral tax burden for both the pre and post tax reform periods are depicted in a multiple bar charts in Figure 2. Evident from the chart is the obvious or significant variation in the pre and post tax burdens generated by the Health $(12.52 \% / 41.44 \%)$, industrial goods $(-13.25 \% / 45.24 \%)$, natural resources sectors $(10.39 \% / 30.37 \%)$ and the agricultural sector $(3.14 \% / 24.98 \%)$. Sectors like services, financial services and construction have little or no real differences in the value of tax burden for the pre and post reform era. The least variation in tax burden before and after the tax is recorded by the service sector which has $21.4 \%$ tax burden before the reform and $22.01 \%$ after the reform. The tax burden of the consumer goods sector is $15.35 \%$ before the reform and $19.77 \%$ after the reform which can also be considered as little variation. The descriptive statistics of the various sector as presented in Table 4 lay credence to these analyses.

Table 4 presents the descriptive statistics of the various sectors before and after the tax reform. For most of the sectors the depicted statistics show no wide variation between the two periods. The additional information provided by Table 4 in respect of the sectoral performances is the minimum and maximum figures and the standard deviation of the tax burden of the pre tax reform and post reform periods. The firm(s) that bears the highest pre reform burden is situated health sector at $70 \%$, this followed by the information sector, this understandable in view of the fact that firms within the sector pay information technology levy which is not generally payable. The natural resources sector appears to contain the firm(s) that bears the least burden of tax before the reform $(-7 \%)$. The consumer goods and the services sectors have within them the firm(s) that appears to pay the highest tax after the tax reform at $52 \%$ and $50 \%$ respectively while firm(s) within the conglomerate sector are faced with the least tax burden post reform.

\subsection{Empirical Results}

The result of the t-test conducted on the pooled data of the whole sample of the study is presented in Table 5. The t-value of the first pair, that is, the tax burdens of before tax reform and after tax reform taxpayers, that is, listed firms, based on the financial statements is -1.326 with a probability index of 0.277 . Since this significant level is greater than the set alpha level of 0.05 , it means that there is no significant difference in the tax burdens of firms before tax reform and after tax reform. Impliedly, the provisions of the tax reform imposed equal or even tax burdens on both the listed firms and do not tilt more favorably/unfavorably towards any of the two times, the pre reform and post reform periods. 


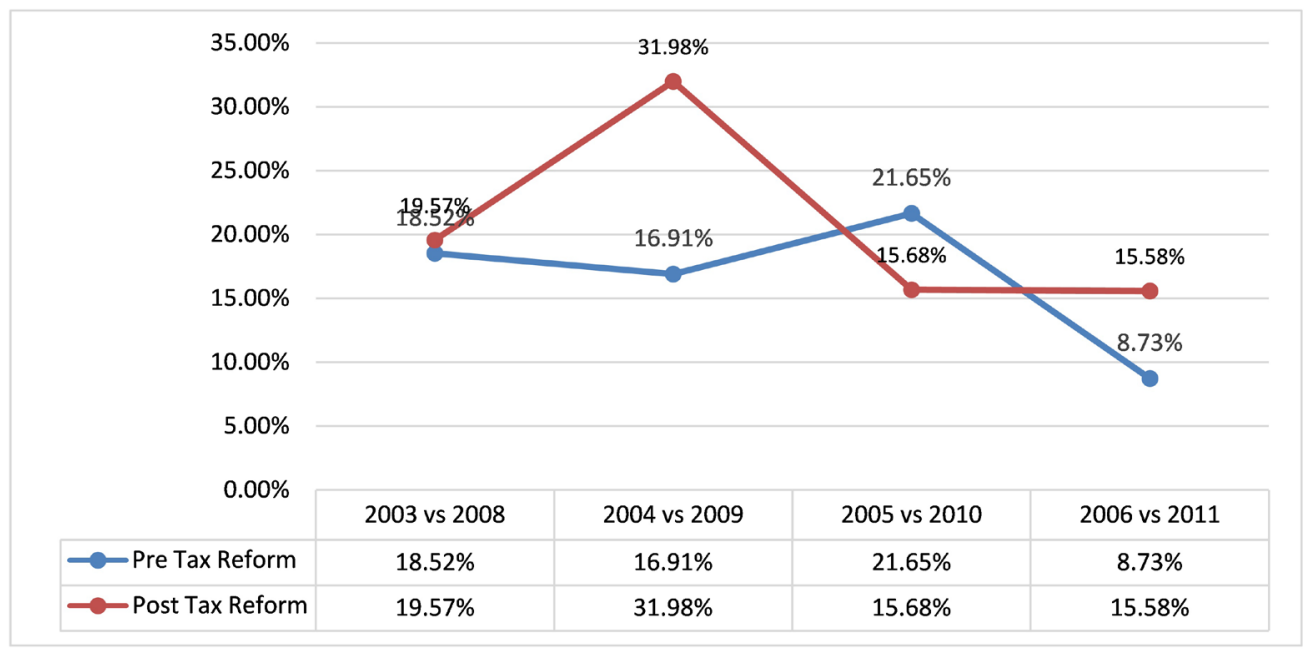

Figure 1. Distribution of average tax burden.

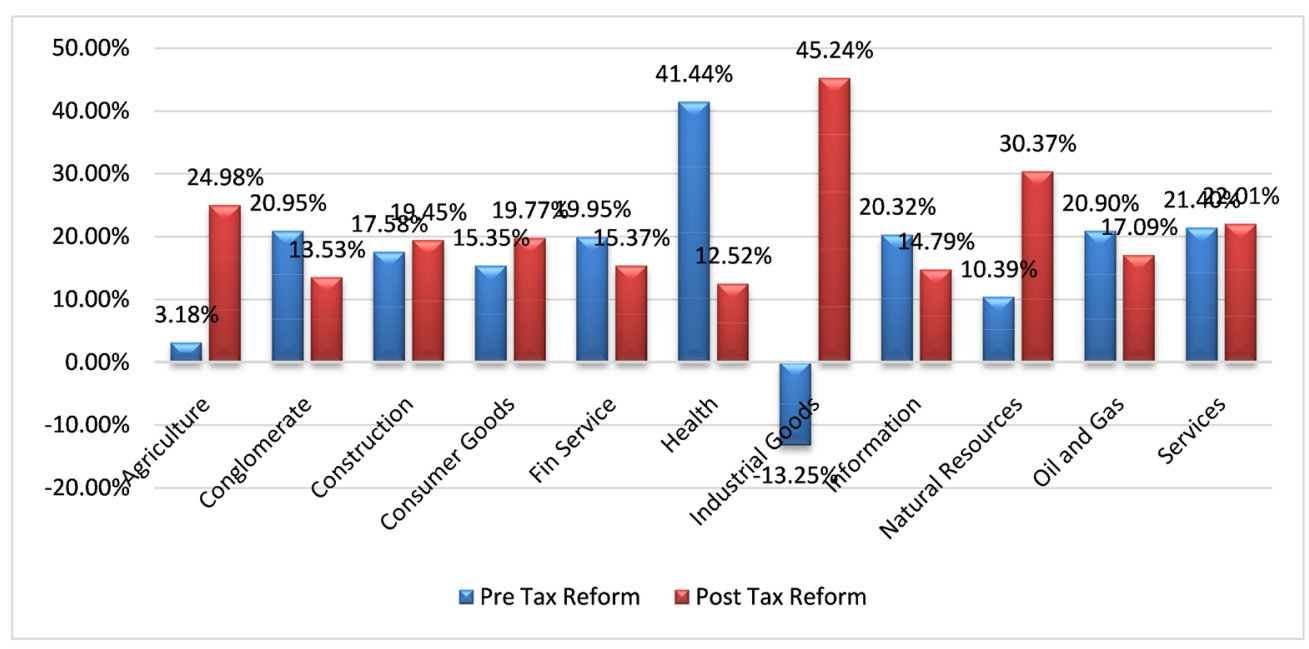

Figure 2. Average sectoral tax burden.

Table 3. Descriptive statistics.

\begin{tabular}{ccc}
\hline & \multicolumn{2}{c}{ Tax burden } \\
\cline { 2 - 3 } Period & Pre tax reform & Post tax reform \\
Range & 344 & 344 \\
Minimum & 1.67 & 1.44 \\
Maximum & -0.97 & -0.10 \\
Mean & 0.70 & 1.35 \\
Std. Error & 0.1621 & 0.2119 \\
Std. Deviation & 0.03282 & 0.03174 \\
Variance & 0.21770 & 0.21055 \\
\hline
\end{tabular}


Table 4. Descriptive statistics for the various sectors.

\begin{tabular}{|c|c|c|c|c|c|c|c|c|c|}
\hline \multirow{2}{*}{ SECTOR } & & \multirow{2}{*}{$\begin{array}{c}\mathrm{N} \\
\text { Statistic }\end{array}$} & \multirow{2}{*}{$\begin{array}{c}\text { Range } \\
\text { Statistic }\end{array}$} & \multirow{2}{*}{$\begin{array}{c}\text { Minimum } \\
\text { Statistic }\end{array}$} & \multirow{2}{*}{$\begin{array}{c}\text { Maximum } \\
\text { Statistic }\end{array}$} & \multicolumn{2}{|c|}{ Mean } & \multirow{2}{*}{$\begin{array}{l}\text { Std. Deviation } \\
\text { Statistic }\end{array}$} & \multirow{2}{*}{$\begin{array}{l}\text { Variance } \\
\text { Statistic }\end{array}$} \\
\hline & & & & & & Statistic & Std. Error & & \\
\hline \multirow{2}{*}{ AGRICULTURE } & $\begin{array}{c}\text { Before } \\
\text { tax reform }\end{array}$ & 12 & 0.06 & 0.01 & 0.07 & 0.0314 & 0.01234 & 0.02468 & 0.001 \\
\hline & $\begin{array}{c}\text { After } \\
\text { tax reform }\end{array}$ & 12 & 0.08 & 0.19 & 0.27 & 0.2294 & 0.01936 & 0.03873 & 0.001 \\
\hline \multirow{2}{*}{ CONGLOMERATE } & $\begin{array}{l}\text { Before tax } \\
\text { reform }\end{array}$ & 20 & 0.24 & 0.06 & 0.29 & 0.2095 & 0.05190 & 0.10381 & 0.011 \\
\hline & $\begin{array}{c}\text { After } \\
\text { tax reform }\end{array}$ & 20 & 0.62 & -0.10 & 0.52 & 0.1353 & 0.13540 & 0.27079 & 0.073 \\
\hline \multirow{2}{*}{ CONSTRUCTION } & $\begin{array}{l}\text { Before tax } \\
\text { reform }\end{array}$ & 12 & 0.08 & 0.15 & 0.23 & 0.1758 & 0.01873 & 0.03746 & 0.001 \\
\hline & $\begin{array}{c}\text { After } \\
\text { tax reform }\end{array}$ & 12 & 0.10 & 0.13 & 0.23 & 0.1945 & 0.02250 & 0.04501 & 0.002 \\
\hline \multirow{2}{*}{$\begin{array}{c}\text { CONSUMER } \\
\text { GOODS }\end{array}$} & $\begin{array}{l}\text { Before tax } \\
\text { reform }\end{array}$ & 68 & 0.09 & 0.10 & 0.19 & 0.1535 & 0.02190 & 0.04380 & 0.002 \\
\hline & $\begin{array}{c}\text { After } \\
\text { tax reform }\end{array}$ & 68 & 0.05 & 0.18 & 0.22 & 0.1977 & 0.00979 & 0.01958 & 0.000 \\
\hline \multirow{2}{*}{ FIN SERVICES } & $\begin{array}{l}\text { Before tax } \\
\text { reform }\end{array}$ & 68 & 0.12 & 0.13 & 0.25 & 0.1994 & 0.02511 & 0.05022 & 0.003 \\
\hline & $\begin{array}{c}\text { After } \\
\text { tax reform }\end{array}$ & 68 & 0.28 & 0.03 & 0.32 & 0.1537 & 0.05961 & 0.11922 & 0.014 \\
\hline \multirow{2}{*}{ HEALTH } & $\begin{array}{l}\text { Before tax } \\
\text { reform }\end{array}$ & 28 & 0.39 & 0.31 & 0.70 & 0.4144 & 0.09517 & 0.19034 & 0.036 \\
\hline & $\begin{array}{c}\text { After } \\
\text { tax reform }\end{array}$ & 28 & 0.14 & 0.06 & 0.20 & 0.1252 & 0.02887 & 0.05774 & 0.003 \\
\hline \multirow{2}{*}{$\begin{array}{l}\text { INDUSTRIAL } \\
\text { GOODS }\end{array}$} & $\begin{array}{l}\text { Before tax } \\
\text { reform }\end{array}$ & 68 & 1.14 & -0.97 & 0.17 & -0.1325 & 0.27914 & 0.55829 & 0.312 \\
\hline & $\begin{array}{c}\text { After } \\
\text { tax reform }\end{array}$ & 68 & 1.22 & 0.13 & 1.35 & 0.4524 & 0.29813 & 0.59627 & 0.356 \\
\hline \multirow{2}{*}{ INFOR } & $\begin{array}{l}\text { Before tax } \\
\text { reform }\end{array}$ & 8 & 0.53 & 0.00 & 0.52 & 0.2052 & 0.11253 & 0.22506 & 0.051 \\
\hline & $\begin{array}{c}\text { After } \\
\text { tax reform }\end{array}$ & 8 & 0.08 & 0.10 & 0.18 & 0.1478 & 0.01733 & 0.03466 & 0.001 \\
\hline \multirow{2}{*}{ NAT RESOURCES } & $\begin{array}{l}\text { Before tax } \\
\text { reform }\end{array}$ & 8 & 0.27 & -0.07 & 0.20 & 0.1039 & 0.06073 & 0.12145 & 0.015 \\
\hline & $\begin{array}{c}\text { After } \\
\text { tax reform }\end{array}$ & 8 & 0.14 & 0.21 & 0.36 & 0.3037 & 0.03240 & 0.06480 & 0.004 \\
\hline \multirow{2}{*}{ OIL AND GAS } & $\begin{array}{l}\text { Before tax } \\
\text { reform }\end{array}$ & 24 & 0.06 & 0.18 & 0.24 & 0.2090 & 0.01526 & 0.03052 & 0.001 \\
\hline & $\begin{array}{c}\text { After } \\
\text { tax reform }\end{array}$ & 24 & 0.03 & 0.15 & 0.19 & 0.1707 & 0.00736 & 0.01472 & 0.000 \\
\hline \multirow{2}{*}{ SERVICES } & $\begin{array}{l}\text { Before tax } \\
\text { reform }\end{array}$ & 28 & 0.18 & 0.11 & 0.30 & 0.2140 & 0.03780 & 0.07561 & 0.006 \\
\hline & $\begin{array}{c}\text { After } \\
\text { tax reform }\end{array}$ & 28 & 0.58 & -0.08 & 0.50 & 0.2201 & 0.12237 & 0.24475 & 0.060 \\
\hline
\end{tabular}


Table 5. Paired samples test.

\begin{tabular}{|c|c|c|c|c|c|c|c|}
\hline & & \multicolumn{3}{|c|}{ Paired Differences } & \multirow[b]{2}{*}{$t$} & \multirow[b]{2}{*}{ Df } & \multirow{2}{*}{$\begin{array}{c}\text { Sig. } \\
\text { (2-tailed) }\end{array}$} \\
\hline & & Mean & $\begin{array}{c}\text { Std. } \\
\text { Deviation }\end{array}$ & $\begin{array}{l}\text { Std. Error } \\
\text { Mean }\end{array}$ & & & \\
\hline Pair 1 & $\begin{array}{c}\text { Before tax reform - After tax } \\
\text { reform }\end{array}$ & -0.09616 & 0.14500 & 0.07250 & -1.326 & 3 & 0.277 \\
\hline
\end{tabular}

The level of similarity between the pre reform tax burden and post reform tax burden, as indicated by the correlation coefficient of the canonical correlation analysis shown in Table 6, is $25.8 \%$. This obvious low correlation coefficient suggests that the two periods' tax burdens are dissimilar at a magnitude (and therefore, the magnitude of the effect of the tax reform) of about $74 \%$, except that it is not significantly so, given that the p-value is 0.742 . Impliedly, the 2007 corporate tax reform had effects which differ over the two time period which are minimal.

Table 7 shows the results of the t-test for the equality of the means of the various industrial sectors. Significant p-values in this table signify sectors with differences in the impact of tax reforms both in the pre and the after periods and the mean difference values explain the direction of the observed effect. A positive mean difference value is observed when the mean of the pre-reform period is greater than the mean of the post-reform period, implying a decrease in the burden occasioned by the tax reform. Conversely, a negative mean difference value is observed when the mean of the post tax reform is greater than the pre tax reform, which implies an increase in tax burden after the tax reform. Consequently, the agricultural and natural resources industrial sectors having t value -8.623 and -2.902 and p-value 0.000 and 0.027 respectively are affected negatively by the 2007 corporate tax reform (meaning higher tax burden). On the other hand, firms within the health and oil and gas sectors with $t$ value of 2.908 and 2.262 and p-value of 0.027 and 0.064 , respectively, have experienced reduced tax burden following the tax reform. Other sectors, as can be seen from Table 7, are unaffected by the tax reform since there is no significant differences in their before and after tax reform tax burdens. It is evident from all the above that the tax reform has lead to varying unequal effects across the different industrial sectors of the economy.

\section{Conclusions}

Following the recommendations of the Study and Work Groups set up by the Federal Government of Nigeria to examine the general tax system in Nigeria and propose amendments to the system, the Companies Income Tax (Amendment) Act 2007 was promulgated to reform the corporate tax system in the country. This study examines the effect of this reform on the tax burden of listed firms. Data were extracted from the annual reports of 86 sampled firms for the period of the study (2003 to 2011) which was delineated into pre-reform (2003-2006) and post-reform (2008-2011) sub-periods. The sample firms were also segregated along their industrial classifications by the Nigerian Stock Exchange. The 
Table 6. Canonical correlation analysis.

\begin{tabular}{ccccc}
\hline & & N & CC Coefficient & Sig. \\
\hline Pair 1 & Before tax reform \& After tax reform & 688 & 0.258 & 0.742 \\
\hline
\end{tabular}

Table 7. Independent samples test for the various sectors.

\begin{tabular}{|c|c|c|c|c|c|c|c|c|}
\hline \multirow{3}{*}{ Sector } & & \multicolumn{7}{|c|}{ t-test for Equality of Means } \\
\hline & & \multirow{2}{*}{$\mathrm{t}$} & \multirow{2}{*}{$\mathrm{df}$} & \multirow{2}{*}{$\begin{array}{c}\text { p-value } \\
\text { (2-tailed) }\end{array}$} & \multirow{2}{*}{$\begin{array}{c}\text { Mean } \\
\text { Difference }\end{array}$} & \multirow{2}{*}{$\begin{array}{l}\text { Std. Error } \\
\text { Difference }\end{array}$} & \multicolumn{2}{|c|}{$\begin{array}{l}\text { 95\% Confidence Interval } \\
\text { of the Difference }\end{array}$} \\
\hline & & & & & & & Lower & Upper \\
\hline AGRICULTURE & & -8.623 & 6 & $0.000^{* * *}$ & -0.19799 & 0.02296 & -0.25418 & -0.14181 \\
\hline CONGLOMERATE & & 0.512 & 6 & 0.627 & 0.07421 & 0.14500 & -0.28060 & 0.42903 \\
\hline CONSTRUCTION & & -0.638 & 6 & 0.547 & -0.01868 & 0.02928 & -0.09033 & 0.05296 \\
\hline CONSUMER GOODS & & -1.843 & 6 & 0.115 & -0.04423 & 0.02399 & -0.10293 & 0.01448 \\
\hline FIN SERVICES & tax burden & 0.707 & 6 & 0.506 & 0.04575 & 0.06468 & -0.11252 & 0.20402 \\
\hline HEALTH & (before and after & 2.908 & 6 & $0.027^{* *}$ & 0.28918 & 0.09945 & 0.04583 & 0.53253 \\
\hline INDUSTRIAL GOODS & tax reforms & -1.432 & 6 & 0.202 & -0.58489 & 0.40842 & -1.58426 & 0.41447 \\
\hline INFOR & & 0.504 & 6 & 0.633 & 0.05733 & 0.11386 & -0.22127 & 0.33593 \\
\hline NAT RESOURCES & & -2.902 & 6 & $0.027^{* *}$ & -0.19975 & 0.06883 & -0.36817 & -0.03133 \\
\hline OIL AND GAS & & 2.262 & 6 & $0.064^{*}$ & 0.03831 & 0.01694 & -0.00314 & 0.07976 \\
\hline SERVICES & & -0.048 & 6 & 0.963 & -0.00614 & 0.12808 & -0.31954 & 0.30725 \\
\hline
\end{tabular}

${ }^{\star} 0.1,{ }^{* *} 0.05,{ }^{* * *} 0.001$ significant.

t-test was carried out to determine any significant differences that might exist between the tax burdens of both periods (and therefore the effect of the tax reform) and the canonical correlation analysis was undertaken to ascertain the magnitude.

The results suggest that, on the average, the tax burdens of the listed firms are unaffected by the 2007 tax reform and vary across the industrial sectors of the economy given that the result of the sectoral analysis reveals some gainer firms (particularly in the health and oil and gas sectors), resulting from the reduction in their tax burden and loser firms in the agricultural and natural resources sectors. These results are in line with the findings of Spengel et al. (2012) [2], Fang et al. (2017) [13], Oroppalo, F. anf Parisi, V. (n.d) [6]. These findings are a useful guide to tax policy makers.

\section{Conflicts of Interest}

The authors declare no conflicts of interest regarding the publication of this paper.

\section{References}

[1] Sanni, A. (2011) Recent Development in Company Taxation in Nigeria. Bulletin of International Taxation, 64, 1-12.

http://online2.ibtfd.org/collections/bit/html/bit_2011_01_ng-html 
[2] Spengel, C., Ortmann-Babel, M., Zinn, B. and Matenaer, S. (2012) A Common Corporate Tax Base for Europe: An Impact Assessment of Draft Council Directive on a CC@TB. World Tax Journal, 4, 185-221.

[3] Roggeman, A., Verleyen, I., Van Cauwenberge, P. and Coppen, C. (2014) Impact of a Common Corporate Tax Base on the Effective Tax Burden in Belgium. Journal of Business, Economics and Management, 15, 530-543. https://doi.org/10.3846/16111699.2013.807869

[4] Spengel, C., Lazar, S., Evers, L. and Zinn, B. (2012) Reduction of Effective Corporate Tax Burden in Romania and Romania's Current Ranking among the Central and Eastern European EU Member States. Post-Communist Economies, 24, 477-502. https://doi.org/10.1080/14631377.2012.729660

[5] Fang, H., Bao, Y. and Zhang, J. (2017) Asymmetric Reform Bonus: The Impact of VAT Pilot Programme on China's Corporate Tax Burden. China Economic Review, 46, 17-34. https://doi.org \10.1016lj.chieco.2017.02.003

[6] Oropalllo, F. and Parisi, V. (n.d) Will Italy's Tax Reform Reduce the Corporate Tax Burden? A Microsimulation Analysis. Societa Italiana di Economic Publica, WP NO 403. http://citeseerx.ist.psu.edulviewdocldownload

[7] Jelilov, G., Abdulrahman, S. and Isik, A. (2017) The Impact of Tax Reforms on Economic Growth of Nigeria. The Empirical Economics Letters, 15, 435-443.

[8] Ogbonna, G.N. and Ebimobwei, A. (2012) Impact of Tax Reforms on Economics Growth of Nigeria: A Time Series Analysis. Current Research Journal of Social Science, 4, 62-68.

[9] Oti, P.A. and Odey, F.I. (2016) Tax Reform and Revenue Trends in Nigeria: The Dyadic Interact. Research Journal of Finance and Accounting, 7, 84-92.

[10] Asaolu, T.O., Dopemu, S.O. and Monday, J.U. (2015) Impact of Tax Reforms on Revenue Generation in Lagos State: A Time Series Analysis. Research Journal of Finance and Accounting, 6, 85-96.

[11] Oriakhi, D.E. and Ahuru, R.R. (2014) The Impact of Tax Reform on Federal Revenue Generation in Nigeria. Journal of Policy and Development Studies, 9, 92-108. https://doi.org/10.12816/0011185

[12] Auerbach, A.J. (1996) Measuring the Impact of Tax Reform. National Tax Journal, 49, 669-673.

[13] Federal Inland Revenue Service (2012) A Comprehensive Tax History of Nigeria. Safari Books Ltd., Ibadan.

[14] Hines Jr., J.R. (2017) Business Tax Burdens and Tax Reform. Brookings Papers on Economic Activity. https://doi.org/10.1353/eca.2017.0019

[15] Hebows, S., Ruf, M. and WEichenvieder, A.J. (2011) The Effect of Taxation on the Location Decision of Multinational Firms M \& A Versus Greenfield. National Tax Journal, 64, 817-838. https://doi.org/10.17310/ntj.2011.3.03

[16] Odusola, A. (2006) Tax Policy Reforms in Nigeria. Research Paper No. 2006/3, United Nations University, World Institute of Development Economics Research.

[17] Federal Inland Revenue Service (2012) Compendium of Tax and Related Laws. Ekundams Press Nig, Abuja.

[18] Nworgu, I.A., Herbert, W.E. and Onyilo, F. (2016) A Longitudinal Assessment of Tax Reforms and National Income in Nigeria 1971-2014. International Journal of Economics and Finance, 8, 43-52. https://doi.org/10.5539/ijef.v8n8p43

[19] Olodo, H.F. (2014) A Critical Analysis of Tax Sector Reforms in Nigeria (1978-2012). LLM Thesis, Ahmadu Bello University, Zaria. 
[20] Anderson, J.E. (2013) US Tax Acts and Their Effect on Average Tax Rates. Applied Economic Letters, 20, 131-134. https://doi.org/10.1080/13504851.2012.684781

[21] Abdel-Mowla, S.A.A. (2013) The Egyptian Tax System Reform, Unvestment and Tax Evasion (2004-2008). Journal of Economics and Administrative Studies, 28, 53-78. https://doi.org/10.1108/10264111211218522

[22] Choi, Y., Hirata, H. and Kim, S. (2017) Tax Reform in Japan: Is It Welfare Enhancing? Japan and the World Economy. (In Press) https://doi.org/10.1016/j.japwor.2017.07.002

[23] Bhattari, K.R. (2007) Welfare Impact of Equal Yield Tax Reform in the UK Economy. Applied Economics, 39, 1545-1563. https://doi.org/10.1080/00036840600571100

[24] Hallerberg, M. and Scartasani, C. (2016) Explaining Changes in Tax Burden in Latin America: Do Politics Trump Economics? European Journal of Political Economy. (In Press)

[25] Peter, V.M., Kerr, I.A. and Thorpe, M. (2002) Tax Policy in India. Asian Journal of Public Administration, 24, 111-138. https://doi.org/10.1080/02598272.2002.10800396

[26] Kryvoruchko, I. (2015) Russia Flat Rate Reform: Redefining Its Effect on Employment. Post-Communist Economies, 27, 188-204. https://doi.org/10.1080/14631377.2015.1026689

[27] Okamoto, A. (2005) Stimulating Fundamental Tax Reforms in Aging Japan. Economic System Research, 17, 163-185. https://doi.org/10.1080/09535310500114911

[28] Feltenstein, A., Mejia, C., Newhouse, D. and Sedrakyan, G. (2017) The Poverty Implication of Alternative Tax Reforms: Results from Numerical Application to Pakistan. Journal of Asian Economies. (In Press) https://doi.org/10.1016/j.asieco.2017.06.004

[29] Guenther, D.J. (1994) Earning Management in Response to Corporate Tax Rate Changes: Evidence from the 1986 Tax Reform Act. The Accounting Review, 69, 230-243.

[30] Dhaliwal, D. and Wang, S. (1992) The Effect of Book Income Adjustment in the 1986 Alternative Minimum on Corporate Financial Reporting. Journal of Accounting and Economics, 15, 7-26. https://doi.org/10.1016/0165-4101(92)90010-Y

[31] Nicodeme, G. (2001) Computing Effective Corporate Tax Rates: Comparison and Results. Economics Paper No. 153. http://eu.int/economy_finance

[32] Scholes, M. and Wolfson, M. (1992) Taxes and Business Strategy: A Planning Approach. Prentice-Hall, Englewood Cliff.

[33] International Accounting Standards Board (2012) International Accounting Standard No. 12: Income Tax Self.

[34] Salaudeen, Y.M. and Akano, R.O. (2018) Nono-Linearity in Determinants of Corporate Effective Tax Rate: Further Evidence from Nigeria. International Journal of Economics and Financial Research, 4, 56-63. 